\title{
Erratum to: Study protocol: evaluation of a parenting and stress management programme: a randomised controlled trial of Triple P Discussion Groups and Stress Control
}

\author{
Melanie L Palmer ${ }^{1,2^{*}}$, Marion Henderson ${ }^{1}$, Matthew R Sanders ${ }^{2}$, Louise J Keown ${ }^{2}$ and Jim White ${ }^{3}$
}

\section{Erratum}

To ensure transparency the authors wish to include the following additional disclosure statement that was not included in the final publication [1]. The Triple P-Positive Parenting Program is owned by The University of Queensland. The University, through its technology transfer company Uniquest Pty Ltd., has licensed Triple P International Pty Ltd to disseminate the program worldwide. Royalties stemming from this dissemination work are distributed to the Faculty of Health and Behavioural Sciences, the School of Psychology, Parenting and Family Support Centre, and contributory authors in accordance with the University's intellectual property policy. No author has any share or ownership in Triple P International.

Matthew Sanders is the founder and an author on various Triple $\mathrm{P}$ programs and a consultant to Triple $\mathrm{P}$ International. Jim White is the founder and lead author of Stress Control. Melanie L Palmer, Marion Henderson, and Louise J Keown declare no competing interests.

\section{Author details \\ ${ }^{1}$ Medical Research Council/Chief Scientist Office Social and Public Health Sciences Unit, University of Glasgow, 4 Lilybank Gardens, Glasgow G12 8RZ, UK. ${ }^{2}$ School of Learning, Development, and Professional Practice, Faculty of Education, The University of Auckland, Private Bag 92601 Symonds St, Auckland 1150, New Zealand. ${ }^{3}$ STEPS Primary Care Mental Health Team, National Health Service Greater Glasgow and Clyde, 60 Florence Street, Glasgow G5 OYX, UK.}

\section{Reference}

1. Palmer ML, Henderson M, Sanders MR, Keown LJ, White J. Study protocol: evaluation of a parenting and stress management programme: a randomised controlled trial of Triple P Discussion Groups and Stress Control. BMC Public Health. 2013;13:888-198. doi:10.1186/1471-2458-13-888.

\footnotetext{
*Correspondence: mpalmer@sphsu.mrc.ac.uk

${ }^{1}$ Medical Research Council/Chief Scientist Office Social and Public Health Sciences Unit, University of Glasgow, 4 Lilybank Gardens, Glasgow G12 8RZ, UK ${ }^{2} S c h o o l$ of Learning, Development, and Professional Practice, Faculty of Education, The University of Auckland, Private Bag 92601 Symonds St Auckland 1150, New Zealand
}

Submit your next manuscript to BioMed Central and take full advantage of:

- Convenient online submission

- Thorough peer review

- No space constraints or color figure charges

- Immediate publication on acceptance

- Inclusion in PubMed, CAS, Scopus and Google Scholar

- Research which is freely available for redistribution

\section{Ciomed Central}

(0) 2015 Palmer et al:; licensee BioMed Central. This is an Open Access article distributed under the terms of the Creative Commons Attribution License (http://creativecommons.org/licenses/by/4.0), which permits unrestricted use, distribution, and reproduction in any medium, provided the original work is properly credited. The Creative Commons Public Domain Dedication waiver (http://creativecommons.org/publicdomain/zero/1.0/) applies to the data made available in this article, unless otherwise stated. 